\title{
Commentary
}

\section{Early antiretroviral therapy for HIV infection in sub-Saharan Africa, a challenging new step}

\author{
Christian Laurent \\ Institut de Recherche pour le Développement (UMR I45), 9I I avenue Agropolis, BP \\ 64501, 34394 Montpellier, Cedex 5, France. \\ E-mail: Christian.Laurent@ird.fr
}

\begin{abstract}
Recent changes in guidelines (World Health Organization (WHO), USA, and likely Europe soon) all move towards earlier initiation of antiretroviral therapy in asymptomatic patients infected with human immunodeficiency virus (HIV). Sonia Menon appropriately questions the feasibility and consequences at both individual and community levels of the early initiation of antiretroviral therapy in sub-Saharan Africa as likely effects will be both positive and negative. Local context should drive the uptake process in every country. Money, national and international, will be essential for the successful implementation of the new WHO recommendation. Leaders at both levels must take their responsibilities and mobilize the necessary resources, for example, doubling those for the Global Fund to Fight AIDS, Tuberculosis

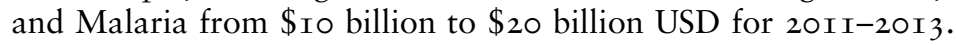

Journal of Public Health Policy (2010) 31, 40I-406. doi:Io.1057/jphp.2010.36

Keywords: Africa; antiretroviral therapy; guidelines; HIV; WHO

Since November 2009, the World Health Organization (WHO) guidelines recommend that low-income countries initiate antiretroviral therapy in asymptomatic or mildly symptomatic patients infected with human immunodeficiency virus (HIV) earlier than was previously recommended, specifically when the $\mathrm{CD}_{4}$ count is less than 350 cells per $\mu \mathrm{L}$ instead of less than 200 cells per $\mu \mathrm{L}$ (also in all symptomatic patients classified at WHO clinical stage 3 or 4 irrespective of the $\mathrm{CD}_{4}$ count). ${ }^{1,2}$ In the last few months, the United States altered its guidelines, increasing the $\mathrm{CD}_{4}$ threshold at which antiretroviral therapy should be initiated $(500$ cells per $\mu \mathrm{L}$ versus 350 cells per $\mu \mathrm{L}$ previously). ${ }^{3,4}$ European guidelines still recommend a threshold of 350 cells per $\mu \mathrm{L}$ (but they have not yet been updated from 2008). . $^{5,6}$ 
Sonia Menon, in this issue of Journal of Public Health Policy, questions the feasibility and consequences at both individual and community levels of the early initiation of antiretroviral therapy in sub-Saharan Africa. ${ }^{7}$ Her questions are appropriate from several points of view. First, sub-Saharan Africa is the continent by far most affected. It has 22.4 million people living with HIV (out of 33.4 million worldwide), I.9 million new infections annually (out of 2.7 million worldwide), and I.4 million annual deaths (out of 2.0 million worldwide). ${ }^{8}$ Second, antiretroviral therapy coverage remains low (roughly a third of the ro million patients in need) despite a major increase in the last few years (I00000 patients treated in 2003) and far from the objective of universal access. ${ }^{9}$ New HIV infections each year remain twice as frequent as treatment initiations. ${ }^{10}$ Third, most African antiretroviral therapy programs adopt the WHO recommendations. Fourth, health system capacities are limited (HIV infection diagnoses occur late, access to $\mathrm{CD}_{4}$ testing is limited, and severe shortages of health workers), especially in the rural settings to which antiretroviral therapy is now decentralized and where most people live. ${ }^{11,12}$ Fifth, the antiretroviral drugs that are available remain limited and most are from the first generation. Last but not least, most African programs are dependent on foreign financial support, with consequent uncertainty about future funding.

The new WHO recommendation was guided by recent data from clinical trials, cohort studies, and mathematical models in high- and low-income countries. They suggest that antiretroviral therapy started at a $\mathrm{CD}_{4}$ count of 350 cells per $\mu \mathrm{L}$ improves survival, delays disease progression and HIV-related morbidity, and is cost-effective. ${ }^{13-16}$ Earlier initiation of antiretroviral therapy is, moreover, expected to reduce HIV transmission by increasing the number of patients with undetectable or low plasma HIV viral load - the main determinant of heterosexual transmission, the predominant type in Africa.

Importantly, the new WHO recommendation should be distinguished from the 'treatment as prevention' strategy (also called 'test and treat' strategy). The latter has been based on universal, voluntary, frequently repeated, HIV testing and immediate initiation of antiretroviral therapy in all infected people irrespective of the immunological and clinical status. ${ }^{17}$ Only the 'treatment as 
prevention' strategy can be expected to reduce dramatically HIV incidence and, in theory, to drive the HIV epidemic towards elimination. The positive impact on HIV prevention of initiating antiretroviral therapy at a $\mathrm{CD}_{4}$ threshold of 350 cells per $\mu \mathrm{L}$ would be much smaller, although appreciable. On the other hand, its negative impact on the health systems would, in the short term, also be smaller.

As described by Menon, the potential negative impact of initiating antiretroviral therapy at a $\mathrm{CD}_{4}$ threshold of 350 cells per $\mu \mathrm{L}$ should not be underestimated, especially in terms of human, financial, and logistic resources required, and subsequent risks associated with resources diversion, especially from prevention and care of the sickest patients. The impact will reflect the number of additional patients attending treatment centers - those asymptomatic or mildly symptomatic with a $\mathrm{CD}_{4}$ count between 200 and 350 cells per $\mu \mathrm{L}$. This additional patient load will, however, be highly dependent on the successful expansion of both HIV testing (through client-initiated and provider-initiated testing) and $\mathrm{CD}_{4}$ testing. ${ }^{18,19}$ Currently, most African patients have a $\mathrm{CD}_{4}$ count below 200 cells per $\mu \mathrm{L}$ and/or are symptomatic at the time they are diagnosed with HIV and are therefore immediately eligible for antiretroviral therapy using the previous WHO guidelines. ${ }^{20}$

$\mathrm{CD}_{4}$ testing is not routine because of infrastructure and financial limitations, especially in rural settings. ${ }^{21}$ Where $\mathrm{CD}_{4}$ testing is not feasible, only symptomatic patients will be treated. Thus WHO's recommendation for early antiretroviral therapy should be considered together with other current recommendations. In the case of the risk of long-term drug toxicity and dissemination of viral resistances, negative impacts of the new WHO recommendation can be expected to be lower when use of second generation, more potent and less toxic antiretroviral drugs (for example, tenofovir substituted for stavudine) expands. In many programs that use nevirapine in first-line regimens, an alternative should be made available because this drug is not recommended in women with a $\mathrm{CD}_{4}$ count above 250 cells per $\mu \mathrm{L}$.

Of course, money will be a cornerstone of the successful implementation of the new WHO recommendation. Additional funds must be mobilized at both international and national levels. The Global Fund to Fight AIDS, Tuberculosis and Malaria, for 
instance, on which many African programs rely will need twice the funds for the 20II-20I3 period, compared to 2008-20IO (US\$ 20 billion versus US\$ 10 billion). ${ }^{22}$ National funds (from households and governments) devoted to HIV/AIDS control contribute only half; more public resources should be allocated to HIV/AIDS (and to the health sector, in general). ${ }^{23}$ In contrast, free access to antiretroviral therapy at the point of delivery should be expanded, as it favors adherence, effectiveness, and equity. ${ }^{24}$ Clearly, these considerable efforts are particularly difficult during the present global economic crisis and will require both political will and innovative solutions.

National AIDS programs managers face a fundamental programmatic challenge: how to adapt and implement the $\mathrm{CD}_{4}$ threshold of 350 cells per $\mu \mathrm{L}$ as recommended by WHO? They must take into account:

- health system capacity (including human and logistic resources);

- number of patients in need of treatment who can be diagnosed and provided care;

- essential activities that must not be penalized as a consequence (for example, prevention, expansion of HIV screening and linkage to care, adherence support, earlier diagnosis, and treatment of HIV-related illnesses);

- other recommendations (for example, availability of $\mathrm{CD}_{4}$ testing, viral load assays, second-line regimens, and newer, more potent and better tolerated antiretroviral drugs; dissemination of viral resistance assessment tools);

- ethical issues (for example, equitable access to care); and

- the level and sustainability of financial resources.

Of particular importance, treatment should not be denied to patients with low $\mathrm{CD}_{4}$ counts (that is, at highest risk of death) because of exceeded capacity.

In conclusion, early initiation of antiretroviral therapy in subSaharan Africa represents a new public health challenge. In each country, the local context should drive the process. Most programs, undoubtedly, will need time to adapt. From now on, international and national political leaders must take on their responsibilities and mobilize the necessary resources. 


\section{About the Author}

\section{Christian Laurent, $\mathrm{PhD}$, is a researcher at the Institut de Recherche pour le Développement, Montpellier, France. His major interests include epidemiology and public health angles of the human immunodeficiency virus infection in Africa.}

\section{References}

I. World Health Organization. (2009) Rapid advice. Antiretroviral therapy for HIV infection in adults and adolescents. November, http://www.who.int/hiv/pub/arv/rapid_advice_art .pdf, accessed 25 August 2010.

2. World Health Organization. (2006) Antiretroviral therapy for HIV infection in adults and adolescents: Recommendations for a public health approach. Revision, http://www .who.int/hiv/pub/guidelines/artadultguidelines.pdf, accessed 25 August 20 Io.

3. Panel on Antiretroviral Guidelines for Adults and Adolescents. Guidelines for the use of antiretroviral agents in HIV-I-infected adults and adolescents. I December 2009; Department of Health and Human Services, http://www.aidsinfo.nih.gov/ContentFiles/ AdultandAdolescentGL.pdf, accessed 25 August 2010.

4. Thompson, M.A. et al (2010) Antiretroviral treatment of adult HIV infection: 2010 recommendations of the international AIDS Society-USA panel. JAMA 304(3): $321-333$.

5. European AIDS Clinical Society. (20I0) Guidelines for the clinical management and treatment of HIV infected adults in Europe, http://www.europeanaidsclinicalsociety.org/ guidelinespdf/I_Treatment_of_HIV_Infected_Adults.pdf, accessed 25 August 2010.

6. British HIV Association. (2008) Guidelines for the treatment of HIV-I infected adults with antiretroviral therapy, http://www.bhiva.org/documents/Guidelines/Treatment\% 20Guidelines/Current/TreatmentGuidelines2008.pdf, accessed 25 August 2010.

7. Menon, S. Early initiation of anti-retroviral therapy and universal HIV testing in subSaharan Africa: Has WHO offered a milestone for HIV prevention? Journal of Public Health Policy 3I(4): $385-400$.

8. UNAIDS. (2009) AIDS epidemic update. November, http://data.unaids.org/pub/Report/ 2009/JCi700_Epi_Update_2009_en.pdf, (cited).

9. World Health Organization. (2006) Towards universal access by 2010. How WHO is working with countries to scale-up HIV prevention, treatment, care and support, http:// www.who.int/hiv/toronto2006/towardsuniversalaccess.pdf, accessed 25 August 2010.

Io. World Health Organization. (2009) Towards universal access. Scaling up priority HIV/ AIDS interventions in the health sector. Progress report 2009, http://www.who.int/hiv/pub/ tuapr_2009_en.pdf, accessed 25 August 20I0.

II. Kober, K. and Van Damme, W. (2004) Scaling up access to antiretroviral treatment in southern Africa: Who will do the job? Lancet 364(9428): 103-I07.

I2. Gilks, C.F. et al (2006) The WHO public-health approach to antiretroviral treatment against HIV in resource-limited settings. Lancet 368(9534): 505-5 IO.

I3. Severe, P. et al (20I0) Early versus standard antiretroviral therapy for HIV-infected adults in Haiti. New England Journal of Medicine 363(3): 257-265.

I4. Kitahata, M.M. et al (2009) Effect of early versus deferred antiretroviral therapy for HIV on survival. New England Journal of Medicine 360(18): I81 5-1826. 
I 5. Sterne, J.A. et al (2009) Timing of initiation of antiretroviral therapy in AIDS-free HIV-Iinfected patients: A collaborative analysis of I 8 HIV cohort studies. Lancet 373(9672): I352-I363.

I6. Walensky, R.P. et al (2009) When to start antiretroviral therapy in resource-limited settings. Annals of Intern Medicine I 5 I(3): I 57-I 66.

I7. Granich, R.M., Gilks, C.F., Dye, C., De Cock, K.M. and Williams, B.G. (2009) Universal voluntary HIV testing with immediate antiretroviral therapy as a strategy for elimination of HIV transmission: A mathematical model. Lancet 373(9657): 48-57.

I8. World Health Organization. (2007) Guidance on provider-initiated HIV testing and counselling in health facilities. May, http://whqlibdoc.who.int/publications/2007/978924I 595568_eng.pdf, accessed 27 August 20 IO.

I9. World Health Organization. (20I0) Delivering HIV test results and messages for re-testing and counselling in adults. 9 June, http://whqlibdoc.who.int/publications/20Io/978924I599II5_ eng.pdf, accessed 27 August 2010.

20. Jaffar, S. et al (2008) Use of WHO clinical stage for assessing patient eligibility to antiretroviral therapy in a routine health service setting in Jinja, Uganda. AIDS Research and Therapy 5(I): 4 .

2I. Kouanfack, C. et al (2010) WHO clinical criteria-based initiation of antiretroviral therapy: Lessons from rural district hospitals in Cameroon with regard to 2009 revised WHO recommendations. Tropical Medicine \& International Health I 5(5): 580-583.

22. The Global Fund to Fight AIDS Tuberculosis and Malaria. (2010) Resource scenarios 20II-20I3. Funding the global fight against HIV/AIDS, tuberculosis and malaria. March, http://www.theglobalfund.org/documents/replenishment/2010/Resource_Scenarios_en .pdf, accessed I September 20 IO.

23. UNAIDS. (2009) What countries need. Investments needed for 2010 targets. February, http://data.unaids.org/pub/Report/2009/JCI68I_what_countries_need_en.pdf, accessed 2 September 2010.

24. Souteyrand, Y.P., Collard, V., Moatti, J.P., Grubb, I. and Guerma, T. (2008) Free care at the point of service delivery: A key component for reaching universal access to HIV/AIDS treatment in developing countries. AIDS 22(I): SI6I-SI68. 